\title{
Synthesis of Nanosized Monocationic $\beta$-Cyclodextrin Conjugates Containing Residues of Pharmacologically Important Acids
}

\author{
Dmitry A. Shipilov, ${ }^{a}{ }^{@}$ Galina I. Kurochkina, ${ }^{a}$ Aleksander A. Sergievich, ${ }^{\text {b }}$ \\ and Mikhail K. Grachev ${ }^{\mathrm{a}}$ \\ ${ }^{\mathrm{a}}$ Moscow State University of Education, 129164 Moscow, Russia \\ ${ }^{\mathrm{b}}$ Far Eastern Federal University, 690091 Vladivostok, Russia \\ ${ }^{\circledR}$ Corresponding author E-mail: shda90@mail.ru
}

\begin{abstract}
New nanosized cationic $\beta$-cyclodextrins conjugates containing residues of pharmacologically important monocarbonic aromatic acids at the primary hydroxyl groups were synthesized with the use of benzoic, p-aminobenzoic, nicotinic and $i$-nicotinic acids. The position of substituents in carbohydrate fragments of CDs was unambiguously determined by ${ }^{1} H$ and ${ }^{13} \mathrm{C}$ NMR spectroscopy. During the investigation, some features of the regiodirected synthesis of such nanosized cationic $\beta$-cyclodextrins conjugates were revealed.
\end{abstract}

Keywords: Cationic cyclodextrins, pharmacologically important acids, esterification, conjugated cyclodextrins, regiodirected synthesis, ${ }^{1} \mathrm{H}$ and ${ }^{13} \mathrm{C}$ NMR spectroscopy.

\section{Синтез наноразмерных монокатионных производных $\beta$-циклодекстрина, содержащих остатки фармакологически важных кислот}

\author{
A. А. Шипилов, ${ }^{a} @$ Г. И. Курочкина, ${ }^{a}$ А. А. Сергиевич, ${ }^{b}$ М. К. Грачев ${ }^{a}$ \\ ${ }^{\mathrm{a}}$ Московский педагогический государственный университет, 129164 Москва, Россия \\ 'Дальневосточный федеральный университет, 690091 Владивосток, Россия \\ ${ }^{\circledR}$ E-mail: shda90@mail.ru
}

Синтезированы новые наноразмерные катионные производные $\beta$-ииклодекстрина, содержащие по первичным гидроксильным группам остатки монокарбоновых ароматических кислот: бензойной, n-аминобензойной, никотиновой и изоникотиновой кислот, представляющих определенный фармакологический интерес. Положение заместителей определяли методами ${ }^{1} \mathrm{H} u{ }^{13} \mathrm{C}$ ЯМР-спектроскопии. В ходе исследования были выявлены некоторые особенности регионаправленного синтеза таких этерифицированных наноразмерных катионных конъюгатов $\beta$-изиклодекстрина.

Ключевые слова: Катионные производные, фармакологически важные кислоты, этерификация, конъюгаты $\beta$-циклодекстрина, регионаправленный синтез, ${ }^{1} \mathrm{H}$ и ${ }^{13} \mathrm{C}$ ЯМР спектроскопия. 


\section{Introduction}

It is well known that cyclodextrins (CDs) (Figure 1), due to their ability to form inclusion complexes of "guesthost" type with appropriate hydrophobic guests, found wide use in pharmacology as containers for numerous drugs. Such encapsulation usually enhances solubility in water and protects drugs from biodegradation. However, this method of drug delivery has some restrictions and shortcomings depending upon equilibrium between the "host" and a "guest", whose degree of association depends, in a complicated manner, on the stability constant of the complex, nature of the solvent, temperature, several other factors. As for medical aspect, it is desirable that the complex would decompose to free CD and the drug at the adsorption site, and then the drug in the free form would enter system circulation. However, when the inclusion complex is "weak", drug delivery is hampered, because the complex dissociates before it reaches the corresponding organ, tissue or cell for which it is designed. ${ }^{[1]}$ For example, the CD complexes are inconvenient for intestinal-specific drug delivery: when orally administrated, the complex often decomposes in the stomach and does not get into the bowels. ${ }^{[2]}$

Therefore, noticeable attention is recently given to the covalent addition (conjugation) of a drug to $\mathrm{CD}$, which, in some cases, allows to obtain drug preparations of more prolongated and targeting site delivery. For the development of this direction special attention has been given during the recent decade to amphiphilic CD derivatives with hydrophobic fragments (usually alkyl or acetyl residues, covalently connected with the primary hydroxyl groups of CD frame) with the purpose for the search for new pharmacological possibilities of CD as excipients of drugs.

From the medical viewpoint, conjugated cyclodextrins with drug molecules (prodrugs) could be used for specific site delivery, while cationic CD derivatives could enhance their ability to penetrate biological barriers, e.g. the bloodbrain barrier, ${ }^{[3]}$ and serve as carriers for DNA delivery (vectorization) under gene therapy. ${ }^{[4-8]}$ We have recently shown the possibility of regiodirected esterification of unprotected $\beta-\mathrm{CD}$ by some pharmacologically important acids $(\mathrm{ROH})$, namely benzoic, $p$-aminobenzoic (vitamin $\mathrm{B}_{10}$ ), nicotinic (vitamin $\mathrm{PP}$, vitamin $\mathrm{B}_{3}$ ), iso-nicotinic (antivitamin PP), and 2-(4-isobutylphenyl)propionic acids (Ibuprofen, anti-fever and anti-inflammatory drug). ${ }^{[9]}$ Preliminary tests of these conjugates displayed promising perspective of their subsequent pharmacological investigations. ${ }^{[10-14]}$

\section{Experimental}

${ }^{1} \mathrm{H}$ and ${ }^{13} \mathrm{C}$ NMR spectra were registered on a JEOL ECX400 spectrometer with working frequency 399.78 and $100.53 \mathrm{MHz}$ respectively. The ${ }^{1} \mathrm{H}$ and ${ }^{13} \mathrm{C}$ chemical shifts are presented relative to tetramethylsilane. Elemental analysis was obtained on a FlashEA 1112 HT instrument. Thin layer chromatography was performed on aluminum plates with fixed layer (Silufol UV-254), eluent: acetonitrile:chloroform (1:1). Commercial $\beta$-cyclodextrin "Wacker" (USA) was dried in vacuum (1 Torr) for $10 \mathrm{~h}$ at $90{ }^{\circ} \mathrm{C}$ over $\mathrm{P}_{2} \mathrm{O}_{5}$ prior to use.

Mono-6-deoxy-6-(tert-butylaminium)- $\beta$-cyclodextrin iodide (3). To a solution of $3.00 \mathrm{~g}$ (2.41 mmol) of mono(6-iodo-6-deoxy)$\beta$-cyclodextrin 2 in $45 \mathrm{~mL}$ of DMF was added at stirring $1.76 \mathrm{~g}$ $(24.10 \mathrm{mmol})$ of tert-butylamine. The solution was stirred for $40 \mathrm{~h}$ at $120-130{ }^{\circ} \mathrm{C}$. The reaction mixture was concentrated to $5 \mathrm{~mL}$, diluted with $25 \mathrm{~mL}$ of acetone, the mixture was stirred, the separated precipitate was filtered off, washed successively with chloroform $(2 \times 5 \mathrm{~mL})$, ethanol $(2 \times 5 \mathrm{~mL})$, acetone $(2 \times 5 \mathrm{~mL})$, ethyl ether $(2 \times 5 \mathrm{~mL})$, and dried in a vacuum $(1 \mathrm{~mm} \mathrm{Hg})$ for $4 \mathrm{~h}$ at $80^{\circ} \mathrm{C}$. Yield $2.59 \mathrm{~g}(82 \%)$. Found (\%): C 42.11; H 6.03; N 0.99. $\mathrm{C}_{46} \mathrm{H}_{80} \mathrm{INO}_{34}$. Calculated (\%): C 41.92; H 6.12; N 1.06. ${ }^{1} \mathrm{H}$ NMR ([D6]DMSO) $\delta_{\mathrm{H}}$ ppm: 1.27 br.s $\left(9 \mathrm{H}, \mathrm{CH}_{3}\right), 3.09-3.95 \mathrm{~m}\left(42 \mathrm{H}, \mathrm{C}^{2} \mathrm{H}-\mathrm{C}^{5} \mathrm{H}, \mathrm{C}^{6} \mathrm{H}_{2}\right)$, 4.34 br.s $\left(6 \mathrm{H}, \mathrm{C}^{6} \mathrm{OH}\right), 4.79$ br.s $\left(7 \mathrm{H}, \mathrm{C}^{1} \mathrm{H}\right), 5.55$ br.s $\left(16 \mathrm{H}, \mathrm{N}^{+} \mathrm{H}_{2}\right.$, $\left.\mathrm{C}^{2} \mathrm{OH}-\mathrm{C}^{3} \mathrm{OH}\right) .{ }^{13} \mathrm{C}$ NMR ([D6]DMSO) $\delta_{\mathrm{C}} \mathrm{ppm}: 25.2\left(\mathrm{CH}_{3}\right), 41.7$ $\left(\mathrm{C}^{6}\right), 47.4\left[C\left(\mathrm{CH}_{3}\right)_{3}\right], 60.4\left(\mathrm{C}^{6}\right), 72.6\left(\mathrm{C}^{5}\right), 73.0\left(\mathrm{C}^{2}\right), 73.6\left(\mathrm{C}^{3}\right), 82.0$ $\left(\mathrm{C}^{4}\right), 102.4\left(\mathrm{C}^{1}\right)$.

6-O-Benzoyl-[6-deoxy-6-(tert-butylaminium)]- $\beta$-cyclodextrin iodide (8). Benzoic acid $4(0.78 \mathrm{~g}, 6.37 \mathrm{mmol})$ and conc. sulfuric acid $(0.12 \mathrm{~g})$ were added to a solution of mono-6-deoxy-6-(tertbutylaminium)- $\beta$-cyclodextrin iodide 3 (1.20 g, $0.91 \mathrm{mmol})$ in $30 \mathrm{~mL}$ of DMF and $5 \mathrm{~mL}$ of benzene at stirring. The mixture was stirred at $120-130{ }^{\circ} \mathrm{C}$ for $6 \mathrm{~h}$, then cooled to $20^{\circ} \mathrm{C}$, and kept for $24 \mathrm{~h}$. The reaction mixture was neutralized with a solution of

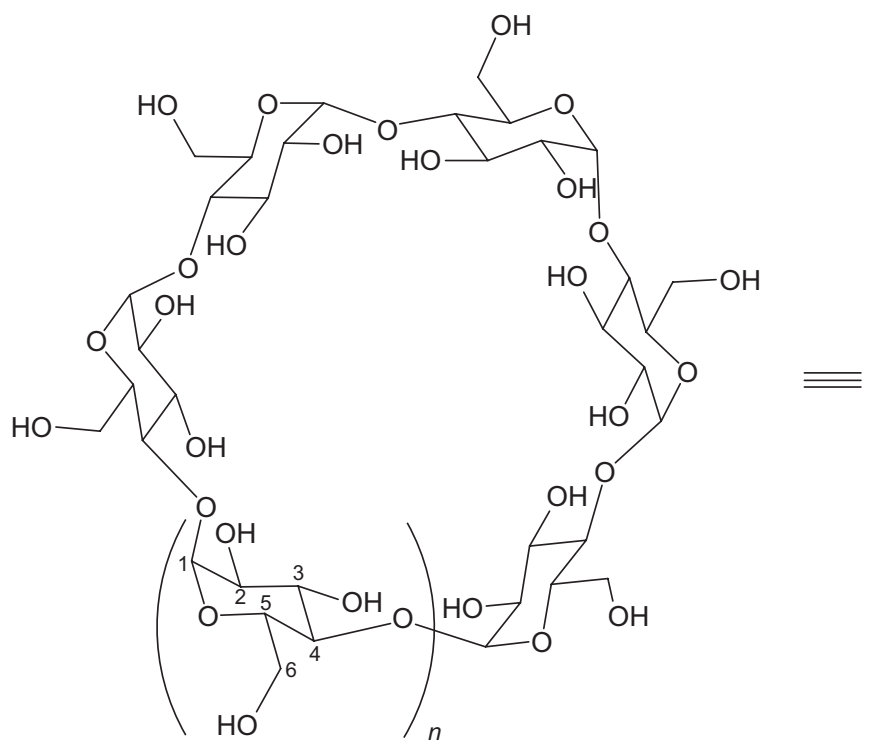

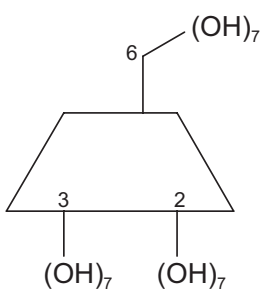

$\beta$ cyclodextrin $(n=2)$

Figure 1. Chemical structure of cyclodextrins. 

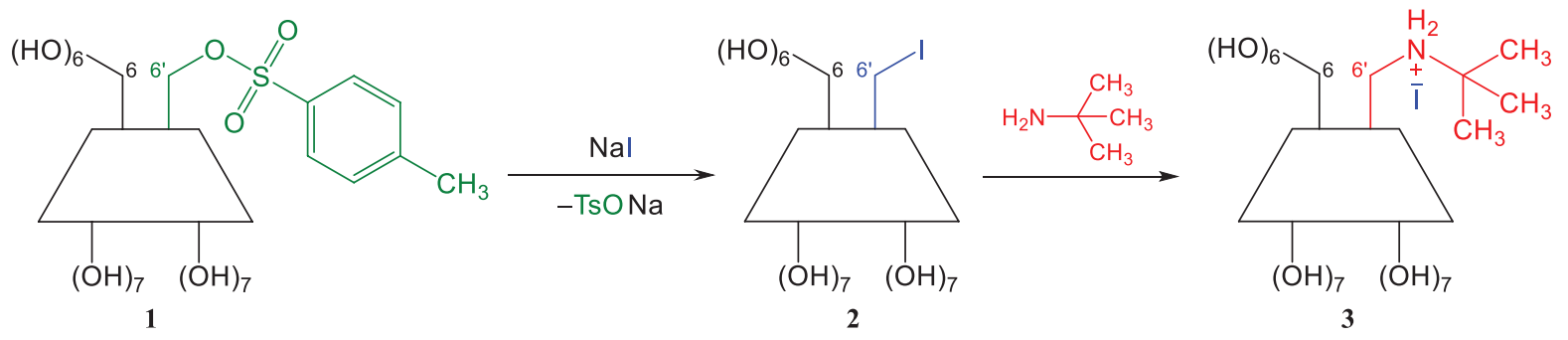

Figure 2. Scheme of the synthesis of $\beta$-cyclodextrin monocationic derivative 3 .

calcium hydroxide, the solution was filtered off, and the filtrate was evaporated to dryness in vacuum. Solid precipitate was triturated with $15 \mathrm{~mL}$ of diethyl ether, filtered off, washed with diethyl ether $(2 \times 5 \mathrm{~mL})$; then with $15 \mathrm{~mL}$ of acetone, filtered off, washed with acetone $(2 \times 5 \mathrm{~mL})$ and dried in vacuum. Yield $0.60 \mathrm{~g}(46 \%)$. M.p. 214-216 ${ }^{\circ} \mathrm{C}$ (decomp.). $\mathrm{R}_{f}=0.68$. Found (\%): C 44.43; H 5.89; $\mathrm{N} 1.02 . \mathrm{C}_{53} \mathrm{H}_{84} \mathrm{INO}_{35}$. Calculated (\%): C 44.76; H 5.95; N 0.98 . ${ }^{1} \mathrm{H}$ NMR ([D6]DMSO) $\delta_{\mathrm{H}}$ ppm: 1.27 br.s $\left(9 \mathrm{H}, \mathrm{CH}_{3}\right), 3.11-3.93 \mathrm{~m}$ $\left(42 \mathrm{H}, \mathrm{C}^{2} \mathrm{H}-\mathrm{C}^{5} \mathrm{H}, \mathrm{C}^{6} \mathrm{H}_{2}\right), 4.34$ br.s $\left(6 \mathrm{H}, \mathrm{C}^{6} \mathrm{OH}\right), 4.79$ br.s $\left(7 \mathrm{H}, \mathrm{C}^{1} \mathrm{H}\right)$, 5.55 br.s $\left(16 \mathrm{H}, \mathrm{N}^{+} \mathrm{H}_{2}, \mathrm{C}^{2} \mathrm{OH}-\mathrm{C}^{3} \mathrm{OH}\right), 7.25-7.67$ br.s $(3 \mathrm{H}, m-\mathrm{CH}$, $p$-CH), $7.91 \mathrm{~d}(2 \mathrm{H}, J 7.8 \mathrm{~Hz}, o-\mathrm{CH}) .{ }^{13} \mathrm{C} \mathrm{NMR}([\mathrm{D} 6] \mathrm{DMSO}) \delta_{\mathrm{C}}$ ppm: $25.2\left(\mathrm{CH}_{3}\right), 41.7\left(\mathrm{C}^{6}\right), 47.4\left[C\left(\mathrm{CH}_{3}\right)_{3}\right], 60.4\left(\mathrm{C}^{6}\right), 65.3\left(\mathrm{C}^{6^{\prime \prime}}\right)$, $72.6\left(\mathrm{C}^{5}\right), 73.0\left(\mathrm{C}^{2}\right), 73.6\left(\mathrm{C}^{3}\right), 82.0\left(\mathrm{C}^{4}\right), 102.4\left(\mathrm{C}^{1}\right), 129.0(m-\mathrm{CH})$, $129.8(o-\mathrm{CH}), 131.2\left[\mathrm{ArC} C^{\mathrm{ipso}} \mathrm{OC}(\mathrm{O})\right], 133.3(p-\mathrm{CH}), 168.3(\mathrm{C}=\mathrm{O})$.

6-O-p-Aminobenzoyl-[6-deoxy-6-(tert-butylaminium)]- $\beta$ cyclodextrin iodide (9) was prepared similarly to compound $\mathbf{8}$ from $p$-aminobenzoic acid 5 (0.87 g, $6.37 \mathrm{mmol})$ and mono-6-deoxy-6(tert-butylaminium)- $\beta$-cyclodextrin iodide $3(1.20 \mathrm{~g}, 0.91 \mathrm{mmol})$. Yield $1.20 \mathrm{~g}\left(88 \%\right.$ ). M.p. $202-204{ }^{\circ} \mathrm{C}$ (decomp.). $\mathrm{R}_{f}=0.73$. Found (\%): C 43.98; H 6.01; N 2.01. $\mathrm{C}_{53} \mathrm{H}_{85} \mathrm{IN}_{2} \mathrm{O}_{35}$. Calculated (\%): $\mathrm{C}$ 44.29; H 5.96; N 1.95. 'H NMR ([D6]DMSO) $\delta_{\mathrm{H}}$ ppm: 1.27 br.s $(9 \mathrm{H}$, $\left.\mathrm{CH}_{3}\right), 3.05-3.94 \mathrm{~m}\left(42 \mathrm{H}, \mathrm{C}^{2} \mathrm{H}-\mathrm{C}^{5} \mathrm{H}, \mathrm{C}^{6} \mathrm{H}_{2}\right), 4.45$ br.s $\left(6 \mathrm{H}, \mathrm{C}^{6} \mathrm{OH}\right)$, 4.78 br.s $\left(7 \mathrm{H}, \mathrm{C}^{1} \mathrm{H}\right), 5.67$ br.s $\left(18 \mathrm{H}, \mathrm{N}^{+} \mathrm{H}_{2}, \mathrm{NH}_{2}, \mathrm{C}^{2} \mathrm{OH}-\mathrm{C}^{3} \mathrm{OH}\right), 6.49$ $\mathrm{d}(2 \mathrm{H}, J 8.2 \mathrm{~Hz}, m-\mathrm{CH}), 7.56 \mathrm{~d}(2 \mathrm{H}, J 8.2 \mathrm{~Hz}, o-\mathrm{CH}) .{ }^{13} \mathrm{C} \mathrm{NMR}$ ([D6]DMSO) $\delta_{\mathrm{C}}$ ppm: $25.2\left(\mathrm{CH}_{3}\right), 41.7\left(\mathrm{C}^{6^{\prime}}\right), 47.4\left[\mathrm{C}\left(\mathrm{CH}_{3}\right)_{3}\right], 60.4$ $\left(\mathrm{C}^{6}\right), 65.3\left(\mathrm{C}^{6^{\prime \prime}}\right), 72.6\left(\mathrm{C}^{5}\right), 73.0\left(\mathrm{C}^{2}\right), 73.6\left(\mathrm{C}^{3}\right), 82.0\left(\mathrm{C}^{4}\right), 102.4\left(\mathrm{C}^{1}\right)$, $113.0(m-\mathrm{CH}), 117.4\left[\mathrm{ArC}^{\mathrm{ipso}} \mathrm{OC}(\mathrm{O})\right], 131.8(o-\mathrm{CH}), 153.7(p-\mathrm{CH})$, $168.0(\mathrm{C}=\mathrm{O})$.

6-O-nicotinoyl-[6-deoxy-6-(tert-butylaminium)]- $\beta$-cyclodextrin iodide (10) was prepared similarly to compound $\mathbf{8}$ from nicotinic acid $6(0.78 \mathrm{~g}, 6.37 \mathrm{mmol})$ and mono-6-deoxy-6-(tertbutylaminium)- $\beta$-cyclodextrin iodide 3 (1.20 g, $0.91 \mathrm{mmol})$. After evaporation, the solid residue was triturated with $5 \mathrm{~mL}$ of ethanol, filtered off, washed with ethanol $(2 \times 5 \mathrm{~mL})$, and dried in vacuum. Yield 0.53 g (43\%). M.p. $208-210{ }^{\circ} \mathrm{C}$ (decomp.). $\mathrm{R}_{f}=0.70$. Found (\%): C 43.73; $\mathrm{H} 5.97 ; \mathrm{N} \mathrm{1.89.} \mathrm{C}_{52} \mathrm{H}_{83} \mathrm{IN}_{2} \mathrm{O}_{35}$. Calculated (\%): C 43.89; $\mathrm{H}$ 5.88; N 1.97. ${ }^{1} \mathrm{H}$ NMR ([D6]DMSO) $\delta_{\mathrm{H}} \mathrm{ppm}$ (here and further the protons and carbons of substituents $\mathrm{R}$ are highlighted with italic): 1.27 br.s $\left(9 \mathrm{H}, \mathrm{CH}_{3}\right), 3.16-3.87 \mathrm{~m}\left(42 \mathrm{H}, \mathrm{C}^{2} \mathrm{H}-\mathrm{C}^{5} \mathrm{H}, \mathrm{C}^{6} \mathrm{H}_{2}\right), 4.44$ br.s $\left(6 \mathrm{H}, \mathrm{C}^{6} \mathrm{OH}\right), 4.78$ br.s $\left(7 \mathrm{H}, \mathrm{C}^{1} \mathrm{H}\right), 5.72$ br.s $\left(16 \mathrm{H}, \mathrm{N}^{2} \mathrm{H}_{2}, \mathrm{C}^{2} \mathrm{OH}-\right.$ $\left.\mathrm{C}^{3} \mathrm{OH}\right), 7.38 \mathrm{~m}\left(1 \mathrm{H}, \mathrm{C}^{5} \mathrm{H}\right), 8.16 \mathrm{~d}\left(1 \mathrm{H}, J 8.0 \mathrm{~Hz}, \mathrm{C}^{4} \mathrm{H}\right), 8.58 \mathrm{~d}(1 \mathrm{H}, J$ $\left.3.9 \mathrm{~Hz}, \mathrm{C}^{6} \mathrm{H}\right), 9.00$ br.s $\left(1 \mathrm{H}, \mathrm{C}^{2} \mathrm{H}\right) .{ }^{13} \mathrm{C}$ NMR ([D6]DMSO) $\delta_{\mathrm{C}} \mathrm{ppm}$ : $25.2\left(\mathrm{CH}_{3}\right), 41.7\left(\mathrm{C}^{6}\right), 47.4\left[\mathrm{C}\left(\mathrm{CH}_{3}\right)_{3}\right], 60.4\left(\mathrm{C}^{6}\right), 65.3\left(\mathrm{C}^{6 \prime}\right), 72.6\left(\mathrm{C}^{5}\right)$, $73.0\left(\mathrm{C}^{2}\right), 73.6\left(\mathrm{C}^{3}\right), 82.0\left(\mathrm{C}^{4}\right), 102.4\left(\mathrm{C}^{1}\right), 123.9\left(\mathrm{C}^{5}\right), 131.6\left(\mathrm{C}^{3}\right)$, $137.1\left(\mathrm{C}^{4}\right), 151.0\left(\mathrm{C}^{2}\right), 151.8\left(\mathrm{C}^{\circ}\right), 169.0(\mathrm{C}=\mathrm{O})$.

6-O-Isonicotinoyl-[6-deoxy-6-(tert-butylaminium)]- $\beta$ cyclodextrin iodide (11) was prepared similarly to compound $\mathbf{8}$ from $i$-nicotinic acid $7(0.78 \mathrm{~g}, 6.37 \mathrm{mmol})$ and mono-6-deoxy-6-(tertbutylaminium)- $\beta$-cyclodextrin iodide 3 (1.20 g, $0.91 \mathrm{mmol})$. Yield 0.77 g (62\%). M.p. $210-212{ }^{\circ} \mathrm{C}$ (decomp.). $\mathrm{R}_{f}=0.70$. Found (\%): $\mathrm{C} 43.65 ; \mathrm{H} 5.95 ; \mathrm{N} 2.11 . \mathrm{C}_{52} \mathrm{H}_{83} \mathrm{IN}_{2} \mathrm{O}_{35}$. Calculated (\%): C 43.89; $\mathrm{H}$ 5.88; N 1.97. ${ }^{1} \mathrm{H}$ NMR ([D6]DMSO) $\delta_{\mathrm{H}}$ ppm: 1.27 br.s $\left(9 \mathrm{H}, \mathrm{CH}_{3}\right)$, $3.07-3.89 \mathrm{~m}\left(42 \mathrm{H}, \mathrm{C}^{2} \mathrm{H}-\mathrm{C}^{5} \mathrm{H}, \mathrm{C}^{6} \mathrm{H}_{2}\right), 4.45$ br.s $\left(6 \mathrm{H}, \mathrm{C}^{6} \mathrm{OH}\right), 4.79$ br.s $\left(7 \mathrm{H}, \mathrm{C}^{1} \mathrm{H}\right), 5.62$ br.s $\left(16 \mathrm{H}, \mathrm{N}^{+} \mathrm{H}_{2}, \mathrm{C}^{2} \mathrm{OH}-\mathrm{C}^{3} \mathrm{OH}\right), 8.11 \mathrm{~d}(2 \mathrm{H}$, $\left.J 5.0 \mathrm{~Hz}, \mathrm{C}^{3} \mathrm{H}, \mathrm{C}^{5} \mathrm{H}\right), 8.92 \mathrm{~d}\left(2 \mathrm{H}, J 5.0 \mathrm{~Hz}, \mathrm{C}^{2} \mathrm{H}, \mathrm{C}^{6} \mathrm{H}\right) .{ }^{13} \mathrm{C} \mathrm{NMR}$ ([D6]DMSO) $\delta_{\mathrm{C}}$ ppm: $25.2\left(\mathrm{CH}_{3}\right), 41.7\left(\mathrm{C}^{6}\right), 47.4\left[\mathrm{C}\left(\mathrm{CH}_{3}\right)_{3}\right], 60.4$ $\left(\mathrm{C}^{6}\right), 65.3\left(\mathrm{C}^{6}\right), 72.5\left(\mathrm{C}^{5}\right), 73.0\left(\mathrm{C}^{2}\right), 73.7\left(\mathrm{C}^{3}\right), 82.1\left(\mathrm{C}^{4}\right), 102.4\left(\mathrm{C}^{1}\right)$, $125.4\left(\mathrm{C}^{3}, \mathrm{C}^{5}\right), 143.2\left(\mathrm{C}^{4}\right), 147.1\left(\mathrm{C}^{2}, \mathrm{C}^{6}\right), 165.4(\mathrm{C}=\mathrm{O})$.

\section{Results and Discussion}

The functionalization of $\beta-\mathrm{CD}$ is made to modify their solubility, their binding behaviour and also to introduce charged groups that enhance the complexation of guest ionic molecules by means of favourable electrostatic interactions, for example. It is known that regioselective modification of cyclodextrins is an experimental challenge due to the presence of different by nature hydroxyl groups: for example, $\beta$-cyclodextrin possesses seven primary and fourteen secondary ones, which are located on a narrow and wide sides of the cyclodextrin skeleton respectively. In synthetic practice for this goal usually the following procedure is being applied: introduction of protective groups to the definite hydroxyl groups, functionalizing of the rest of hydroxyl groups and finally removing of the protective groups with the formation of the target compound ${ }^{[5,15-17]}$ For preparation of the monosubstituted $\beta$-cyclodextins on the primary hydroxyl groups, monotosylation and following substitution of the tosyl fragment with the appropriate nucleophilic reagent containing labile hydrogen atom is most often applied. ${ }^{[5,17]}$ In the present work, we have synthesized new nanosized ${ }^{\dagger}$ monocationic $\mathrm{CD}$ derivatives (conjugates), containing residues of benzoic, $p$-aminobenzoic, nicotinic and iso-nicotinic acids at primary hydroxyl groups of the CD frame.

The preparation of cationic derivatives commonly utilizes 6-azido-6-deoxy cyclodextrin derivatives that are converted into amines by treating with triphenylphosphine in aqueous ammonia. ${ }^{[15,17]}$ However this method possesses a limitation since it is suitable only for the preparation of aminium cyclodextrin derivatives from primary amines. We considered the possibility of the synthesis of monocationic derivatives from $\beta$-cyclodextrin monohalo derivatives and the corresponding amine. With some amines the preparation of aminium salts is possible. For instance, at the direct

\footnotetext{
†ote, that in pharmacology the optimal "nanosize" values are within 1-100 nm. ${ }^{[18]}$ For example, doxorubicin, the well-known antitumour agent, which in free state is very toxic for both affected and healthy cells, in a nanosized form easily penetrates the bloodbrain barrier and manage in many cases the brain tumour. ${ }^{[19-20]}$
} 

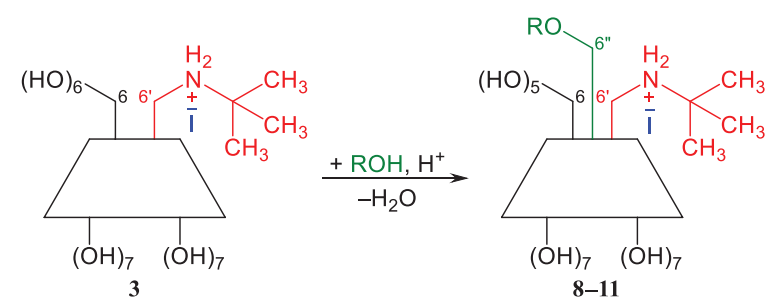

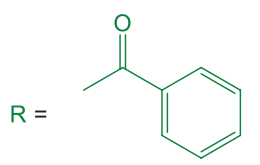

4,8
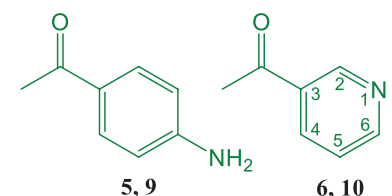

6,10

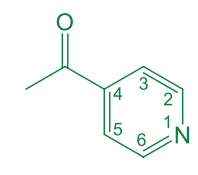

7,11

Figure 3. Esterification of $\beta$-cyclodextrin monocationic derivative 3

treatment of $\beta$-cyclodextrin tosylate with pyridine cationic compound was obtained, but $p$-toluenesulfonic acid was fairly strongly retained in the cyclodextrin cavity. ${ }^{[21]}$

At the first stage, from $\beta$-cyclodextrin monotosylate $\mathbf{1}^{[22]}$ the synthesis of iodo derivative 2 was performed by procedure [23]: (Figure 2).

Monohalo derivative 2 was obtained in $79 \%$ yield. The structure and regiodirection of the substitution in cyclodextrins $\mathbf{1 , 2}$ is confirmed by the ${ }^{1} \mathrm{H}$ and ${ }^{13} \mathrm{C}$ NMR data. All ${ }^{13} \mathrm{C}$ NMR spectra of compounds 1,2 contain signals of unsubstituted C-6 atoms at $\delta 60.4 \mathrm{ppm}$. The spectra of monotosylate $\mathbf{1}$ is characterized by the appearance in the downfield region of minor signals from C- 6 ' bearing substituent OTs at $\delta 69.7 \mathrm{ppm}$, and in the spectrum of iodosubstituted compound $\mathbf{2}$ the corresponding signal attached to iodine at $\delta 15.3 \mathrm{ppm}$. No additional signals from C-2 and C-3 nuclei were observed in the spectrum of compound 1 showing that only the hydroxy group at the atom C-6' underwent the substitution.

The content of the halogen introduced in the $\beta$-cyclodextrin molecule was confirmed by argentometric titration. ${ }^{[25]}$ The weight portion ( $\left.\sim 0.04 \mathrm{~g}\right)$ of compound $\mathbf{2}$ was mineralized by Schöniger method followed by titration with $0.01 \mathrm{~N}$ silver nitrate solution.

Iodo derivative 2 was brought in reaction with tertbutylamine to obtain monocationic aminium $\beta$-cyclodextrin derivative 3 (Figure 3). The synthesis was carried out in DMF at $120-130{ }^{\circ} \mathrm{C}$ for $40 \mathrm{~h}$ to receive in $82 \%$ yield compound 3 with the positive charge on the side of the primary hydroxy groups of the cyclodextrin scaffold. The structure of compound $\mathbf{3}$ was confirmed by ${ }^{1} \mathrm{H}$ NMR data, and the regiodirection of the substitution of the primary hydroxy groups was revealed from the ${ }^{13} \mathrm{C}$ NMR data. To be able to integrate the carbon signals in the ${ }^{13} \mathrm{C}$ NMR spectra of compound $\mathbf{3}$ the registration was performed at a large delay between the pulses $(8 \mathrm{~s})$. The ${ }^{13} \mathrm{C}$ NMR spectra of compound 3 contain the signals of nuclei of unsubstituted C- 6 atoms at

\footnotetext{
* From the numerous methods of monotosylate 3 preparation ${ }^{[27]}$ we chose the procedure from this paper ${ }^{[22]}$ as the most reliable and efficient.

$\S$ Hereinafter strokes mark the CD carbon atoms at which the hydroxyl groups are substituted.
}

$\delta 60.4$ ppm and characteristic minor upfield signals of C-6' nuclei bearing the $\mathrm{N}^{+}$substituent at $\delta 41.7 \mathrm{ppm}$.

At the second stage, we performed esterification of monocationic derivatives by monocarboxylic aromatic compounds to obtain derivatives 8-11 (Figure 3). The esterification was performed in DMF/benzene solution at $120-130{ }^{\circ} \mathrm{C}$ for $3 \mathrm{~h}$ in the presence of a catalytic amount of sulfuric acid.

Monoesterification was confirmed by the data of ${ }^{1} \mathrm{H}$ NMR spectroscopy; substitution regioselectivity was proven by ${ }^{13} \mathrm{C}$ NMR spectroscopy. In ${ }^{13} \mathrm{C}$ NMR spectra of compounds 8-11 the signals of nuclei of unsubstituted atoms C-6 at $\delta$ $60.4 \mathrm{ppm}$ were observed together with the typical up-field minor signals of carbon nuclei C-6' bearing substituent $\mathrm{N}^{+}$ at $\delta 41.7 \mathrm{ppm}$ and the typical down-field minor signals of carbon nuclei C-6" bearing substituent OR at $\delta 65.3 \mathrm{ppm}$. At the same time, no shifts of the signals from $\mathrm{C}-2$ and $\mathrm{C}-3$ were observed, indicating that these positions were not involved in esterification. The $\mathrm{OH}$ proton positions were identified by their considerable shift (by $0.3-0.8 \mathrm{ppm}$ ) at elevated temperature $\left(80^{\circ} \mathrm{C}\right)$.

The correctness of the signals assignment of all obtained compounds 1-3, 8-11 was additionally confirmed by the analysis of 2D NMR spectra of homo- (HOMOCOR $\left\{{ }^{1} \mathrm{H}-\right.$ $\left.{ }^{1} \mathrm{H}\right\}$ ) and heteronuclear (HETCOR $\left\{{ }^{1} \mathrm{H}-{ }^{13} \mathrm{C}\right\}$ ) correlations and registering in the DEPT mode.

It is interesting to note that the attempts of more profound acylation under the discussed conditions occurred to be unsuccessful and led to accumulation of by-products in the reaction mixture only. This fact confirmed earlier observations stated on preliminary incapsulation of an acid (guest) into hydrophobic cavity of cyclodextrin (host) before acylation as it was mentioned in paper. ${ }^{[26]}$ Analogous phenomenon was observed previously by us. ${ }^{[27-30]}$ It should be noted that in synthetic practice for the direct esterification of primary hydroxyl group water-removing catalysts are usually used such as dicyclohexylcarbodiimide, and the others. In our case, due to a possibility of inclusion of such catalysts into a cavity of the cyclodextrin, esterification in the presence of sulfuric acid occurred to be preferable.

\section{Conclusions}

Thus, with the use of benzoic, $p$-aminobenzoic, nicotinic and $i$-nicotinic acids we have proposed new and simple procedures for the regiodirected synthesis of nanosized cationic $\beta-\mathrm{CD}$ derivatives containing the residues of pharmacologically important acids at the primary hydroxyl groups. It is expected that such compounds are of interest for medical and biological studies in various directions.

Acknowledgements. This work was performed under financial support of the Russian Foundation for Basic Research (Project No. 16-03-00444).

\section{References}

1. Rajewski R.A., Stella V.J. J. Pharm. Sci. 1996, 85, 1142-1169.

2. Uekama K., Hirayama F., Irie T. Chem. Rev. 1998, 98, 20452076. 
3. Perly B., Moutard S., Djedaïni-Pilard F. PharmaChem 2005 (Jan/Feb), 4-9.

4. Sallas F., Darcy R. Eur. J. Org. Chem. 2008, 957-969.

5. Zafar N., Fessi H., Elaissari A. Int. J. Pharm. 2014, 461, 351366.

6. Mével M., Yaouanc J.J., Laurent P., Clément J.C., Cartier D., Jaffrès P.A., Montier T., Delépine P., Le Gall T., Lehn P., Pichon C., Midoux P., Férec C. Phosphorus, Sulfur Silicon Relat. Elem. 2008, 183, 460-468.

7. Mével M., Lamarche F., Clément J.C., Yaouanc J.J., Laurent P., Burel L., Giamarchi P., Montier T., Delépine P., Lehn P., Jaffrès P.A., Férec C. Phosphorus, Sulfur Silicon Relat. Elem. 2008, 183, 745-746.

8. Bienvenu C., Martínez A., Jiménez Blanco J.L., Di Giorgio C., Vierling P., Mellet C.O., Defaye J., García Fernández J.M. Org. Biomol. Chem. 2012, 10, 5570-5581.

9. Shipilov D.A., Kurochkina G.I., Rasadkina E.N., Vasyanina L.K., Soboleva N.O., Grachev M.K. Russ. J. Gen. Chem. 2015, 85, 2605-2608.

10. Batalova T.A., Dorovskih V.A., Sergievich A.A., Plastinin M.L., Grachev M.K., Kurochkina G.I., Lysenko S.A. Dal'nevostochnyi Meditsinkiy Zhurnal 2008, 105-107 (in Russ.).

11. Batalova T.A., Dorovskih V.A., Kurochkina G.I., Grachev M.K., Sergievich A.A., Plastinin M.L. Bulleten' Experimental'noi Biologii i Meditsiny 2011, 151, 642-645 (in Russ.).

12. Batalova T.A., Dorovskih V.A., Sergievich A.A., Plastinin M.L., Grachev M.K., Kurochkina G.I., Lysenko S.A., Badasyan A.N. Russ. Fed. Pat. 2363 473, 2008.

13. Batalova T.A., Grachev M.K., Kurochkina G.I. Russ. Fed. Pat. 2429 017, 2011.

14. Batalova T.A., Grachev M.K., Kurochkina G.I. Russ. Fed. Pat. 2440 370, 2011.

15. Boger J., Corcoran R.J., Lehn J.-M. Helv. Chim. Acta 1978, 61, 2190-2218.

16. Croft A.P., Bartsch R.A. Tetrahedron 1983, 39, 1417-1474.
17. Khan A.R., Forgo P., Stine K.J., D’Souza V.T. Chem. Rev. 1998, 98, 1977-1996.

18. Shimanovsky N.L., Yepinetov M.A., Mel'nikov M.Ya. Molecular and Nano-Pharmacology. Moscow: Phizmatlit, 2010. 624 p. (in Russ.) [Шимановский Н.Л., Епинетов М.А., Мельников М.Я. Молекулярная и Нанофармакология. М.: Физматлит, 2010. 624 с.].

19. Gelperina S., Maksimenko O., Khalansky A., Vanchugova L., Shipulo E., Abbasova K., Berdiev S., Vohlfart S., Chepurnova N., Kreuter J. Eur. J. Pharm. Biopharm. 2010, 74, 157-163.

20. Chen Y., Pang Y., Wu J., Su Y., Liu J., Wang R., Zhu B., Yao Y., Yan D., Zhu X., Chen Q. Langmuir 2010, 26, 9011-9016.

21. Béjaoui I., Baâzaoui M., Chevalier Y., Amdouni N., Kalfat R., Hbaieb S. J. Incl. Phenom. Macrocycl. Chem. 2016, 86, 79-92.

22. Byun H.-S., Zhong N., Bittman R. Org. Synth. Coll. 2004, 10, 690.

23. Melton L.D., Slessor K.N., Carbohydr. Res. 1971, 18, $29-37$.

24. Tripodo G., Wischke C., Neffe A.T., Lendlein A., Carbohydr. Res. 2013, 381, 59-63.

25. Klimova V.A. Basic Micromethods for Analysis of Organic Compounds. Moscow: Khimiya, 1967. p. 224 (in Russ.) [Климова В.А. Основные микрометоды анализа органических соединений. М.: Химия, 1975. 224 с.].

26. Coates J.H., Easton C.J., Fryer N.L., Lincoln S.F. Chem. Lett. 1994, 1153-1156.

27. Glazyrin A.E., Syrtsev A.N., Kurochkina G.I., Kononov L.O., Grachev M.K., Nifant'ev E.E. Russ. Chem. Bull. 2003, 52, 237-246.

28. Grachev M.K., Edunov A.V., Kurochkina G.I., Popkov A.V., Levina I.I., Nifant'ev E.E. Russ. J. Org. Chem. 2011, 47, 284 289.

29. Grachev M.K., Edunov A.V., Kurochkina G.I., Soboleva N.O., Vasyanina L.K., Nifant'iev E.E. Russ. Chem. Bull. 2012, 61, 181-187.

30. Malenkovskaya M.A., Grachev M.K., Levina I.I., Nifant'ev E.E. Russ. J. Org. Chem. 2013, 49, 1777-1782. 